\title{
Passwords
}

Volume 12 | Issue 2

Article 4

6-4-2012

\section{Art After Hours}

Rachel Brownell

rpb02011@mymail.pomona.edu

Follow this and additional works at: http://scholarship.claremont.edu/passwords

Cart of the Art and Design Commons, $\underline{\text { Creative Writing Commons, and the Photography }}$ Commons

\section{Recommended Citation}

Brownell, Rachel (2012) "Art After Hours," Passwords: Vol. 12: Iss. 2, Article 4. DOI: 10.5642/passwrd.20121202.4

Available at: http://scholarship.claremont.edu/passwords/vol12/iss2/4

This Poetry is brought to you for free and open access by the Journals at Claremont at Scholarship @ Claremont. It has been accepted for inclusion in

Passwords by an authorized administrator of Scholarship@ Claremont. For more information, please contact scholarship@cuc.claremont.edu. 


\section{Art After Hours \\ Rachel Brownell}

Paint-stained fingertips,

Fruit-stained nailprints,

Laughter melted on our lips.

Candy hearts pool red \& white

On rough denim cuffs

Turned stiff by the acrylic night.

Tables topped with milk-swirled cheese

Tight grape skins, canvas-stretch,

Yield to fresh wet color-bursts: seize,

Release, let thick pigments swarm with peace.

We held and stared and moved with ease

Among those silvery drips of so many minds

Which, when combined

Let sing spontaneity to make magnificence of time. 